\title{
ECONOMIC FACTORS IN THE CHOICE OF STUDIES AND WORK
}

\author{
Aija Sannikova ${ }^{1}$, Dr.oec.; Velga Vevere ${ }^{2}$, Dr.phil.; Tamara Grizane ${ }^{3}$, Dr.oec. and Liga \\ Jankova ${ }^{4}$, Dr.oec. \\ ${ }^{1,2}$ University of Economics and Culture, ${ }^{3}$ Turiba University, ${ }^{4}$ Latvia University of Life Sciences and Technologies
}

\begin{abstract}
The research analysed changes in earnings in the regions of Latvia in the period 2010-2017 and the effect of the factor "earnings" on the choice of a university study programme by students and on the demand for jobs by the students in the labour market. The research conducted a survey of students $(n=391)$ from seven Bachelor programmes pertaining to two fields - services and social sciences as well as business and law. A nonparametric Mann-Whitney $U$ test revealed that in the choice of a programme for a profession, the factor "earnings" was statistically more significant than the factors "opportunity to do creative work", "skill stability in the future" and "opportunity to work flexible hours", while in the demand for a job it was more significant than the factor "enterprise reputation among the public".
\end{abstract}

Key words: study programme and job choice factors, earnings, higher education, corporate social responsibility, Latvia.

JEL code: J30, I25, Z31, O15.

\section{Introduction}

One of the aspects of corporate social responsibility (CSR) relates to the improvement of the life quality of the society, which is affected also by individuals' responsible attitude to education, learning a profession and choosing a job. Informed and motivated actions of individuals in relation to their careers help the society to be aware of the strengths concerning human resources and to provide the supply of specialists for the national economy.

Research aim: to analyse the role of economic factors in the choice of study programmes and the demand for jobs in Latvia. Research tasks: 1) to examine theoretical findings on factors for the choice of studies and work; 2) to conduct a survey and analyse the effects of economic factors on the choice of a study programme by students and on the demand for jobs by the students. Research methods: the research employed qualitative methods for a theoretical literature review, a survey of students $(n=391)$ at universities established by legal entities with regard to two fields - services and social sciences as well as business and law - and statistical analysis. Research sources and materials: information provided by the Central Statistical Bureau of Latvia, documents, statistics and research studies done in Latvia and by international organizations. Research limitations. The research defines the concept of study programme choice factors as the motivational factors of individuals in their choice of a certain study programme in higher education (ISCED levels 4-6); the concept of job demand factors is defined as the motivational factors of individuals to offer their labour services to enterprises or institutions; the concept of economic factors is defined as earnings in the labour market and the demand for labour in the labour market for a particular profession. The research performed an analysis of economic and other factors - their importance - and a comparative analysis of the economic factors.

\section{Research results and discussion}

The educational environment is dynamic, which is also determined by the fact that the population of Latvia is expected to considerably decline. Compared with 2015, the population is expected to decline by $3.7 \%$ in 2020 and $12.2 \%$ by 2030 (Eurostat, 2019). The change in the population, which is based on specific assumptions regarding the birth rate, the death rate and migration for the country, requires considering rational use of human resources in the economy, while universities

\footnotetext{
${ }^{1}$ Contacts to be added to the author, as a footnote at the bottom of the first page ( 6 point Verdana font)
} 
have to focus on enhancing their competitiveness in order to attract future students. This consideration is important also because the total population of the EU-28 is expected to increase, compared with 2015, by $1.2 \%$ in 2020 and $3.0 \%$ in 2030. Because of a smaller number of future students, it will be difficult for universities in Latvia to compete with universities in other countries in terms of education quality, as university resources (academic personnel, financial resources etc.) are associated with the number of students. One of the ways to contribute to the engagement of working individuals in higher education is to build up their understanding of whether the competences they plan to acquire meet labour market needs and whether their competences will contribute to the achievement of their individual goals, which represents the corporate social responsibility of the universities. Even though there is an opinion that a profession has to be chosen based on one's own calling and enjoyment of the profession (Dietz 2010), nowadays it is difficult to believe that in the era of economic uncertainty individuals could choose this philosophy as the leading motive and would not base their decisions on economic considerations for the choice of a field of studies and a programme.

The authors believe that individuals act rationally to achieve a higher level of prosperity and implement their ideas, and economic factors are involved in it. Any choice of studies is determined by an individual's future goals, abilities, values and the particular circumstances. Individuals' decision to begin studies is important at the micro-level, and this decision together with other choices made cause socio-economic consequences, thereby affecting the availability of specialists in the labour market.

A study of students' choices of studies done at six universities in Scotland, for two Bachelor programmes (accounting and engineering), revealed that the decisions were determined by a complex of factors (Briggs S., 2006) - the place of residence, the academic reputation of the university and the distance between the university and the residence place, which might be regarded as an indirect economic factor because the longer the distance is, the higher the transport cost is. Other studies found that the choice of a study programme was mainly affected by the student's personal traits and interest in the profession (Worthington, A., Higgs, H., 2004). A formal assessment of the individual's knowledge in key courses, understanding of economic development in the country and knowledge of the relevant industry are important as well. Often, the choice of a profession and a job is encouraged by the relative cost of studies and the economic benefits the individual gets in the life by working in the profession. This means that the expected cash flow in the future, which includes at least earnings and other benefits, encourage individuals to make investments in their education. However, the decision is affected by the study load - the higher the study load to learn the profession, the smaller the number of individuals wishing to learn the profession (Worthington, A., Higgs, H., 2004).

The rational approach is not the only aspect regarding acquiring education, many individuals are guided by their emotions and intuition; accordingly, both individual and interpersonal relation factors are important (Edmonds J., 2012). Studies have proved that individuals tend to be conservative in relation to making investments in building up their competences under difficult socio-economic conditions.

A new aspect in higher education in Latvia is the internationalisation of the environment for university studies. Universities seek to create a favourable environment for foreign students (Roga R., Lapina I., Muurseppc P., 2015); therefore, research should be focused on how the new situation affects the wish of residents to choose the programmes in which foreigners are enrolled. In assessing 
the environment for studies, five components are important to potential students: logistics, teaching and learning, assistance for studies, advice and marketing, yet the level of importance of these factors, depending on the form of studies, varies for the students (Bailey, M., Ifenthaler, D., Kretzschmar, M., 2014). The fact that many individuals begin university studies not right after graduating from secondary school but after having some work experience is considered to be important; for this reason, this category of individuals needs a supportive and adapted environment for studies.

A decision on the choice of a career might be affected also by parents and teachers, yet prospects for employment and earnings in the profession are referred to as one of the dominant factors (Fizer, D. 2013). A survey of undergraduate students $(N=226)$ studying engineering and business conducted at five universities showed that the choice of the programmes was affected by: 1) higher education prestige among the public and the reputation of the university; 2) economic factors such as employment opportunities and career prospects. This means that the excellence and the price of the environment for studies, which has to be paid for the use of it, is balanced with future opportunities in the labour market.

In view of the role of earnings, which was identified in the examination of theoretical findings, in the rational choices made by individuals for their future, the research analysed statistical data on changes in earnings in the regions of Latvia and Riga region in particular. Average net earnings rose in all the regions of Latvia in the period 2010-2017, while the highest earnings were reported in Riga region (Fig. 1). In 2017, the disparity in average net earnings between the region with the lowest earnings - Latgale (EUR 471) - and Riga region reached EUR 297, which was $50.3 \%$ higher than in 2010. The changes in earnings in Riga region in the period 2010-2017 demonstrated a linear trend $\left(R^{2}=0.9807\right),(1)$ :

$$
y=36.226 x+456.86
$$

where:

$x$ - period $(x=t+n), R-$ determination coefficient.

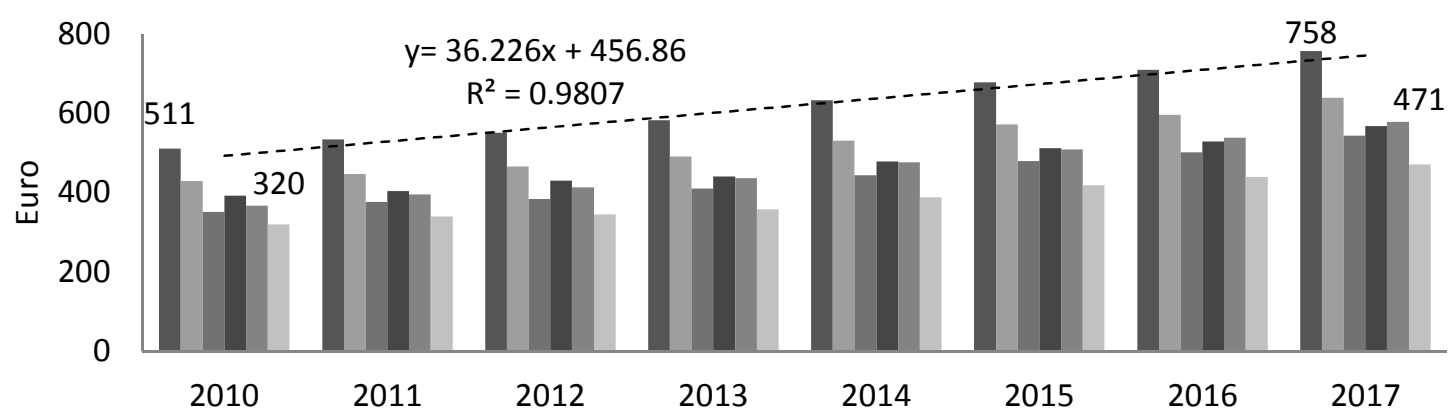

Riga region $\square$ Pieriga region $\square$ Vidzeme region $\square$ Kurzeme region $\square$ Zemgale region $\square$ Latgale region Source: authors' calculations based on CSB, 2019c

Fig. 1. Average net earnings in the regions of Latvia in the period 2010-2017

However, despite the positive trend in average earnings observed in Latvia in recent years, in 2017 the earnings were lower in Latvia than Estonia: average gross earnings in Latvia reached EUR 926 (7.8 \% increase compared with 2016) (CSB, 2019c), while in Estonia - EUR 1221 (Statistics Estonia, 2019). In 2017, $11.3 \%$ of the total population of Latvia was very poor, which was 6.0 percentage points higher than the average in the EU-28 (CSB, 2019a).

There were significant disparities in average monthly earnings across industries in Latvia, as the average gross earnings paid to those engaged in financial and insurance activities were the highest 
(EUR 1921), whereas those engaged in accommodation and food service activities had the lowest earnings (EUR 634), thereby making a disparity range of EUR 1287 for the average gross earnings.

The authors believe that this disparity could be a reason why economic returns from education are important to potential students and employees.

In the labour market of Latvia, according to earlier research studies, the demand for and supply of labour are not aligned quantitatively and qualitatively (Sannikova, A., Grizane, T.,2018; LDDK, 2018), which results in vacant jobs and contributes to a surplus of specialists with higher education. The working population declines in the following age groups: 15-24, 25-39 and 40-64 (Sannikova A., Grizane T., Dobele A., 2017). The human resources available in the labour market decrease because of the negative demographic situation.

An empirical research study was done by the authors in 2018. The authors believe that the research could help universities and employers to better understand the behavioural motives of the working population for acquiring new skills and offering their skills in the labour market.

To achieve the research aim, the authors selected a stratified sample of respondents. The survey was done in Riga region at three universities established by legal entities and at a college that delivered programmes in two fields: services and social sciences as well as business and law. The survey involved first-year students in the spring semester of the academic year 2017/18 and the autumn semester of the academic year 2018/19, encompassing seven Bachelor programmes (Accounting and Audit, Management, Creative Marketing and Sales Management, Business Management, Tourism and Hospitality Enterprise Management, International Communication Management, Journalism and Media, Entertainment and Recreational Industry Management). The sample was representative at a confidence level of $95 \%$ and a significance level of $\pm 5 \%$.

The respondents were requested to rate factors for the choice of a programme and the demand for jobs on a Likert scale (very important - 5, not important-1). The factors were rated by two student groups ( $n_{1}=15 ; n_{1}=12$ ) in the spring semester $2017 / 18$ who rated how important the factors were and then compared the factors with each other.

Totally, 412 questionnaires were distributed, and 391 were valid for data processing $(94.9 \%$ of the total). Of the total respondents who gave replies, 224 were women (57.3\%) and 167 were men $(42.7 \%) ; 83.6 \%$ were full-time employees, $8.2 \%$ were part-time employees and $8.2 \%$ were not employed (mostly those studying full-time). Since the survey was conducted in Riga region, the respondents mainly represented this region (59.1\%). The second largest group was from Pieriga region $(23.8 \%)$, while the percentage of respondents from the regions of Vidzeme and Kurzeme was the same $(4.1 \%)$. The smallest group represented Latgale region with $0.5 \%$.

The factors for the choice of a study programme included in the questionnaire were divided into two categories: 1) economic factors (earnings; demand for specialists in the labour market); 2) other factors that could be subdivided into several subcategories: skill stability in the future, work arrangement- and working environment-related factors and employer corporative social responsibility for the quality of human resources. The present research does not analyse data on subcategory respondent ratings.

The research divided the respondent replies regarding the factors affecting the choice of a study programme and the demand for jobs (on the part of employees) into two categories: 1) important, which comprised the respondents' ratings that, on a Likert scale, corresponded to "very important" (5) and „important" (4); unimportant, which. corresponding to "moderately important" (3), slightly important" (2) and "not important" (1). The results showed that the economic factors - earnings and 
demand for specialists in the labour market - were important ones in the choice of a study programme; besides, the factor "earnings" was referred to in $88 \%$ instances (Table 1). As regards the demand for jobs by potential employees, earnings were as important as enterprise reputation (both factors were referred to in $91.7 \%$ instances). An important factor was "skill stability in the future", as this factor was referred to $72 \%$ in instances. One can conclude that the choice of a study programme was affected by the individual's knowledge of the labour market and understanding of change in the demand for skills in the labour market; another important aspect was the corporate social responsibility of universities concerning building up the skills in students that are in demand in the labour market at least in a medium-term and that could be transformed into new competences.

Table 1

Percentage breakdown of respondent replies regarding factor importance

\begin{tabular}{|c|c|c|c|c|c|c|}
\hline \multirow{3}{*}{$\begin{array}{l}\mathbf{N} \\
\mathbf{0}\end{array}$} & \multirow{3}{*}{ Factor } & \multirow{3}{*}{ 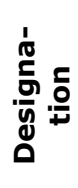 } & \multicolumn{4}{|c|}{ Degree of importance } \\
\hline & & & \multicolumn{2}{|c|}{ Important* } & \multicolumn{2}{|c|}{ Unimportant** } \\
\hline & & & $\begin{array}{c}\text { Tot } \\
\text { al }\end{array}$ & $\begin{array}{l}\text { \% of total } \\
\text { ratings }\end{array}$ & $\begin{array}{l}\text { Tot } \\
\text { al }\end{array}$ & $\begin{array}{l}\text { \% of total } \\
\text { ratings }\end{array}$ \\
\hline
\end{tabular}

Importance of factors in the choice of a study programme

\begin{tabular}{|l|l|c|c|c|c|c|}
\hline 1. & Earnings & A & 22 & $\mathbf{8 8 . 0}$ & 3 & 12.0 \\
\hline 2. & Opportunity to do creative work & B & 15 & 60.0 & 10 & 40.0 \\
\hline 3. & Demand for specialists in the labour market & C & 19 & $\mathbf{7 6 . 0}$ & 6 & 24.0 \\
\hline 4. & Employer support for studies & D & 14 & 56.0 & 11 & 44.0 \\
\hline 5. & Skill stability in the future & E & 18 & $\mathbf{7 2 . 0}$ & 7 & 28.0 \\
\hline 6. & Opportunity to work remotely & F & 6 & 24.0 & 19 & 76.0 \\
\hline 7. & Opportunity to work in a foreign company & G & 6 & 24.0 & 19 & 76.0 \\
\hline 8. & Opportunity to work flexible hours & H & 15 & 62.5 & 9 & 37.5 \\
\hline 9. & IT application opportunities & I & 6 & 25.0 & 18 & 75.0 \\
\hline
\end{tabular}

9. Importance of factors in the demand for jobs

\begin{tabular}{|l|l|c|c|c|c|c|}
\hline $\mathbf{1}$ & J. & 22 & $\mathbf{9 1 . 7}$ & 2 & 8.3 \\
\hline $\begin{array}{l}\mathbf{1} \\
\mathbf{1}\end{array}$ & Enterprise reputation among the public & $\mathrm{K}$ & 22 & $\mathbf{9 1 . 7}$ & 2 & 8.3 \\
\hline $\begin{array}{l}\mathbf{1} \\
\mathbf{2}\end{array}$ & Observance of ethics at the enterprise & $\mathrm{L}$ & 20 & 83.3 & 4 & 16.7 \\
\hline $\begin{array}{l}\mathbf{1} \\
\mathbf{3}\end{array}$ & $\begin{array}{l}\text { Working environment standards at the } \\
\text { enterprise }\end{array}$ & $\mathrm{N}$ & 20 & 83.3 & 4 & 16.7 \\
\hline $\begin{array}{l}\mathbf{1} \\
\mathbf{4}\end{array}$ & $\begin{array}{l}\text { Engagement of the enterprise in } \\
\text { environmental protection }\end{array}$ & $\mathrm{M}$ & 13 & 54.2 & 11 & 45.8 \\
\hline $\begin{array}{l}\mathbf{5} \\
\mathbf{5}\end{array}$ & IT solutions at the enterprise & $\mathrm{O}$ & 12 & 50.0 & 12 & 50.0 \\
\hline $\begin{array}{l}\mathbf{1} \\
\mathbf{6 .}\end{array}$ & Occupational safety at the enterprise & $\mathrm{P}$ & 16 & 66.7 & 8 & 33.3 \\
\hline
\end{tabular}

Notes: important*- "very important" (rated at 5), "important" (rated at 4); unimportant **- "moderately important" (rated at 3), "slightly important" (rated at 2), "not important" (rated at 1)

Source: authors' calculations

To identify whether the respondents' ratings of the factor "earnings" (most important one) in relation to the choice of a programme and the demand for jobs were statistically significant, the research did a Mann-Whitney $U$ test by employing the tools of SPSS 21 . The test results are summarised in Table 2.

According to the results, the hypothesis $\mathrm{H}_{0}\left(\mathrm{H}_{0}\right.$ : the factor "earnings" and another factor are rated equally) has to be rejected in the first, fourth and eight cases (Table 2). This means that at a confidence level of $95 \%$, the role of the factor "earnings" $(A)$ in the choice a study programme was 
greater than those of the factor "opportunity to do creative work" ( $B ; p=0,314>0.05)$, the factor "skill stability in the future" ( $E ; p=0,700>0.05)$ and the factor "opportunity to work flexible hours" $(H ; p=0,138>0.05)$. Even though the factor "earnings" $(A)$ for the choice of a study programme was rated higher than in other instances (e.g. the mean rank of the factor "earnings" (A) was 30.66, while the mean rank of the factor "demand for specialists in the labour market" was 20.34), it was of a casual nature.

Table 2

\section{Mann-Whitney test results for a comparison of the factor "earnings" with the other factors}

\begin{tabular}{|c|c|c|c|c|c|c|}
\hline No & Group & $\mathbf{N}$ & Mean Rank & Mann-Whitney U & $\mathbf{Z}$ & Asymp. Sig. (2-tailed) \\
\hline \multicolumn{7}{|c|}{ Comparison of factors affecting the choice of study programmes } \\
\hline 1. & $\begin{array}{l}A \\
B\end{array}$ & $\begin{array}{l}25 \\
25\end{array}$ & $\begin{array}{l}27.42 \\
23.58\end{array}$ & 264.500 & -1.007 & 0.314 \\
\hline 2. & $\begin{array}{l}\mathrm{A} \\
\mathrm{C}\end{array}$ & $\begin{array}{l}25 \\
25\end{array}$ & $\begin{array}{l}30.66 \\
20.34\end{array}$ & 183.500 & -2.690 & 0.007 \\
\hline 3. & $\begin{array}{l}A \\
D\end{array}$ & $\begin{array}{l}25 \\
25 \\
\end{array}$ & $\begin{array}{l}29.86 \\
21.14 \\
\end{array}$ & 203.500 & -2.229 & 0.026 \\
\hline 4. & $\begin{array}{l}\mathrm{A} \\
\mathrm{E}\end{array}$ & $\begin{array}{l}25 \\
25\end{array}$ & $\begin{array}{l}26.24 \\
24.76\end{array}$ & 294.000 & -0.385 & 0.700 \\
\hline 5. & $\begin{array}{l}A \\
G\end{array}$ & $\begin{array}{l}25 \\
25\end{array}$ & $\begin{array}{l}34.06 \\
16.94\end{array}$ & 98.500 & -4.274 & 0.000 \\
\hline 6. & $\begin{array}{l}\mathrm{A} \\
\mathrm{H}\end{array}$ & $\begin{array}{l}25 \\
24\end{array}$ & $\begin{array}{l}27.80 \\
22.08 \\
\end{array}$ & 230.000 & -1.485 & 0.138 \\
\hline 7. & $\begin{array}{l}\text { A } \\
\text { I }\end{array}$ & $\begin{array}{l}25 \\
24\end{array}$ & $\begin{array}{l}33.48 \\
16.17\end{array}$ & 88.000 & -4.380 & 0.000 \\
\hline \multicolumn{7}{|c|}{ Comparison of factors affecting the demand for jobs } \\
\hline 8. & $\begin{array}{l}\mathrm{J} \\
\mathrm{K}\end{array}$ & $\begin{array}{l}24 \\
24 \\
\end{array}$ & $\begin{array}{l}27.56 \\
21.44 \\
\end{array}$ & 214.500 & -1.728 & 0.084 \\
\hline 9. & $\begin{array}{l}\mathrm{J} \\
\mathrm{L}\end{array}$ & $\begin{array}{l}24 \\
24 \\
\end{array}$ & $\begin{array}{l}29.69 \\
19.31 \\
\end{array}$ & 163.500 & -2.840 & 0.005 \\
\hline 10. & $\mathrm{~J}$ & $\begin{array}{l}24 \\
24\end{array}$ & $\begin{array}{l}29.42 \\
19.58\end{array}$ & 170.000 & -2.685 & 0.007 \\
\hline 11. & $\mathrm{~J}$ & $\begin{array}{l}24 \\
24\end{array}$ & $\begin{array}{l}31.35 \\
17.65\end{array}$ & 123.500 & -3.639 & 0.000 \\
\hline 12. & $\begin{array}{l}\mathrm{J} \\
\mathrm{O}\end{array}$ & $\begin{array}{l}24 \\
24\end{array}$ & $\begin{array}{l}31.54 \\
17.46\end{array}$ & 119.000 & -3.730 & 0.000 \\
\hline 13. & $\begin{array}{l}\mathrm{J} \\
\mathrm{P}\end{array}$ & $\begin{array}{l}24 \\
24 \\
\end{array}$ & $\begin{array}{l}29.63 \\
19.38 \\
\end{array}$ & 165.000 & 2.774 & 0.006 \\
\hline
\end{tabular}

Note: factors included in a category are showed in Table 2

Source: authors' calculations

The respondents' replies revealed that at a confidence level of $95 \%$, the factor "earnings" in relation of the demand for jobs ( $\mathrm{J}$ ) was more important than the factor "enterprise reputation among the public" (mean $\operatorname{rank}(J)=27.56 ;$ mean $\operatorname{rank}(K)=23.58 ; p=0.314>0.05)$. In other cases, the higher ratings of the factor "earnings" $(\mathrm{J})$ were of a casual nature.

\section{Conclusions, proposals, recommendations}

- In the scientific arena, the factors affecting the choice of a study programme are extensively researched, stressing the quality of the environment for studies, the prestige of universities, the individual's personal traits, opportunities for employment, returns from education as well as other factors.

- The present research revealed that quantitatively, the factor "earnings" was rated higher than the factor "demand for specialists in the labour market". The nonparametric Mann-Whitney U test confirmed that in the choice of a study programme, the factor "earnings" in the profession was 
statistically more significant than the factors "opportunity to do creative work" and "skill stability in the future", while in the demand for a job it was more significant than the factor "enterprise reputation among the public". The research has to be continued to identify whether there are regional differences in rating the factor "earnings", as the earnings are different across the regions of Latvia. The responsibility of universities for building up skills in students should be continued to be researched as one of the aspects of corporate social responsibility in the context of changes occurring in the labour market.

\section{Bibliography}

1. Bailey, M., Ifenthaler, D., Kretzschmar, M., (2014). Factors Influencing Tertiary Students' Choice of Study Mode. Retrieved:

https://www.researchgate.net/publication/288454306_Factors_influencing_students'_choice_of_study_mod e_An_australian_case_study

2. Briggs, S. (2006). An Exploratory Study of the Factors Influencing Undergraduate Student Choice: the Case of Higher Education in Scotland. Studies in Higher Education, 31 (6), 705-722. Retrieved: https://www.tandfonline.com/doi/abs/10.1080/03075070601004333

3. Edmonds, J. (2012). An Exploratory Study of the Factors Influencing Undergraduate Student Choice: the Case of Higher Education in Scotland. Rowan University, May 1, 2012. Retrieved: https://rdw.rowan.edu/cgi/viewcontent.cgi?article=1146\&context=etd

4. Eurostat (2018). Population Projections. Retrieved: https://ec.europa.eu/eurostat/tgm/table.do?tab=table\&init=1\&language=en\&pcode=tps00002\&plugin $=1$

5. Calkins, L.N., Andy Welki, A. (2006). Factors that Influence Choice of Major: Why Some Students Never Consider Economics. Article in International Journal of Social Economics 33 (August):547-564 . August 2006 with 868 Reads. DOI: 10.1108/03068290610678707 Source: RePEc. Retrieved: https://www.researchgate.net/publication/23948988_Factors_that_influence_choice_of_major_Why_some_ students_never_consider_Economics

6. Fizer, D. (2013). Factors Affecting Career Choices of College Students Enrolled in Agriculture. A Research Paper Presented for the Master of Science in Agriculture and Natural Resources Degree the University of Tennessee, Martin. December 2013. Retrieved: https://www.utm.edu/departments/msanr/_pdfs/Fizer_Research_Project_Final.pdf

7. LDDK (2018). LDDK: Latvia Needs to Solve the Problem of Availability of a Qualified Workforce (in Latvian). LETA. Retrieved: https://www.delfi.Iv/bizness/biznesa_vide/lddk-latvija-jarod-risinajumus-kvalificetadarbaspeka-pieejamibas-nodrosinasanai.d?id=50393887

8. Central Statistical Bureau of Latvia. (2019a). Poverty Risk and Social Exclusion in Latvia. EU-SILC 2017 Survey Results (in Latvian). Retrieved: https://www.csb.gov.Iv/Iv/statistika/statistikas-temas/socialieprocesi/nabadziba/meklet-tema/365-nabadzibas-risks-un-sociala-atstumtiba-latvija

9. Central Statistical Bureau of Latvia. (2019b). Social Processes. DSDSG010. Average Monthly Wages and Salaries (in euro; as per cent of previous year). Retrieved: http://data1.csb.gov.Iv/pxweb/Iv/sociala/sociala_dsamaksa_ikgad/DSG010.px/table/tableViewLayout1/?r xid=44712b66-ad50-4aa6-a1c7-d7c0f3dbb517

10. Central Statistical Bureau of Latvia. (2019c). Social Processes. DSG060. Average Monthly Gross Wages and Salaries in Statistical Regions by Kind of Activity (in euro). Retrieved: http://data1.csb.gov.Iv/pxweb/Iv/sociala/sociala_dsamaksa_ikgad/DSG060.px/table/tableViewLayout1/?r xid=44712b66-ad50-4aa6-a1c7-d7c0f3dbb517

11. Roga, R., Lapina, I., Muurseppc, p. (2015). Internationalization of Higher Education: Analysis of Factors Influencing Foreign Students' Choice of Higher Education Institution. Retrieved: https://www.sciencedirect.com/science/article/pii/S1877042815058619

12. Sannikova, A., Grizane, T., Dobele, A. (2017). Demand for and Supply of Higher Education in Latvia. In: Economic Science for Rural Development 2017, Latvia, Jelgava, 27.04.2017-28.04.2017. Jelgava: LLU, pp. 204-212. ISBN 978-9984-48-261-3. ISSN 1691-3078. ISSN 2255-9930.

13. Sannikova, A., Grizane, T. (2018). Labour Supply in Latvia and Its Impacting Factors. No: Proceedings of the 2018 International Conference "Economic Science for Rural Development": The 2018 International Conference "Economic Science for Rural Development", Latvia, Jelgava, 09.05.2018-11.05.2018. Jelgava: LLU, pp. 237-243; Retrieved: http://www.esaf.Ilu.Iv/sites/esaf/files/files/lapas/Krajums_Nr_48_01.05.2018.pdf. Retrieved: DOI 10.22616/ESRD.2018.090.

14. Statistics Estonia (2019). Average Monthly Gross Wages (Salaries). Retrieved: https://www.stat.ee/stataverage-monthly-gross-wages-salaries

15. Worthington, A., Higgs, H. (2004). Factors Explaining the Choice of an Economics Major: The Role of Student Characteristics, Personality and Perceptions of the Profession. In: International Journal of Social Economics. Retrieved: https://www.emeraldinsight.com/doi/abs/10.1108/03068290410529416 